Article

\title{
Phreatic Water Quality Assessment and Associated Hydrogeochemical Processes in an Irrigated Region Along the Upper Yellow River, Northwestern China
}

\author{
Fei Liu ${ }^{1,2}$, Zhipeng Zhao ${ }^{3}$, Lihu Yang ${ }^{4,5, *}$, Yuxue Ma ${ }^{6}$, Bingliang $\mathrm{Li}^{7}$, Liang Gong ${ }^{6}$ \\ and Haiyan Liu ${ }^{6}$ \\ 1 School of Water Conservancy and Hydropower, Hebei University of Engineering, Handan 056000, China; \\ liuf.13b@igsnrr.ac.cn \\ 2 Department of Hydrology and Atmospheric Sciences, University of Arizona, Tucson, AZ 85721, USA \\ 3 Geological Bureau of Ningxia Hui Autonomous Region, Yinchuan 750021, China; \\ zhaozhipeng.1986@163.com \\ 4 Key Laboratory of Water Cycle and Related Land Surface Processes, Institute of Geographic Sciences and \\ Natural Resources Research, Chinese Academy of Sciences, Beijing 100101, China \\ 5 Sino-Danish College, Univerisity of Chinese Academy of Sciences, Beijing 101400, China \\ 6 Ningxia Geological Survey Institute, Yinchuan 750021, China; dzdx-myx@163.com (Y.M.); \\ gl121203@126.com (L.G.); liuhaiyan0117@126.com (H.L.) \\ 7 School of Water Resource and Environment, China University of Geosciences, Beijing 100083, China; \\ 2105170031@cugb.edu.cn \\ * Correspondence: yanglihu@igsnrr.ac.cn; Tel.: +86-1861-231-7419
}

Received: 14 January 2020; Accepted: 6 February 2020; Published: 10 February 2020

\begin{abstract}
Groundwater resources are playing an increasingly vital role in water supply for domestic and irrigation purposes in the Yinchuan Plain, along with the reduction in water transfer from the Yellow River. This study aimed to identify the current status of phreatic water quality and associated hydrogeochemical processes in an irrigated region along the upper Yellow River. A total of 78 water samples were collected in September 2018 for chemical analysis. Results showed that the phreatic water was excellent or good in most areas west of the Yellow River, while it was poor or very poor quality in some places east of the Yellow River. The nitrate contamination is particularly severe in the pluvial-alluvial plain, relating to the localized fine-grained zone with low permeability. Most samples had no sodium hazard but had magnesium hazard. Additionally, the overall evolutionary trend of the phreatic water showed the transformation of $\mathrm{Ca}-\mathrm{Mg}-\mathrm{HCO}_{3}$ into Na-Cl-SO 4 type. Rock weathering and evaporation jointly predominate the evolution of phreatic water chemistry. The main geochemical processes involve the dissolution/precipitation of gypsum, halite, dolomite. and calcite, along with the cation exchange. Insights from this work have important implications for groundwater sustainable management in such irrigated regions along the upper Yellow River.
\end{abstract}

Keywords: groundwater quality; hydrogeochemical processes; water-rock interaction; water quality index; Yellow River irrigated areas

\section{Introduction}

Groundwater is one of the most precious water sources for residents in semi-arid and arid regions of the world. Due to the shortage of surface water, groundwater is increasingly pumped for drinking and irrigation purposes in the arid regions [1]. With the rapid development of China's economy, the gap between water supply and demand in the northwest is widening each year. As a major challenge in building a new and sustainable Silk Road Economic Belt, threats induced by poor groundwater 
management have raised stress on the groundwater resources in the Yinchuan Plain, Northwestern China. The Yinchuan Plain is one of the oldest irrigated areas in Northwest China along the Silk Road economic belt, where nearly three million population depend on groundwater for drinking [2]. Water diversion from the Yellow River through a network of canals and ditches is the primary source of artificial irrigation [3]. Due to high permeability and shallow water depth in the Yinchuan plain, phreatic aquifers are highly vulnerable to pollution. As a consequence, the contamination of phreatic aquifer is aggravated by long-term application of chemical fertilizers in agricultural activities, which seriously restrict economic development in the Yinchuan Plain [4]. With significant reduction in water transfer from Yellow River, groundwater acts as an increasingly important role for drinking water and irrigation, which is viewed as an important water source to ensure crop yields, especially during dry periods. In this study, an irrigated area in the middle part of the Yinchuan Plain is selected to represent the irrigated regions along the upper Yellow River, where agriculture predominates the local economy. Phreatic water is the major source for domestic and irrigation uses in the irrigated region. The chemical characteristics of natural water in this region have been greatly regulated by human interferences (such as irrigation, groundwater exploitation, etc.). These pressures make the dynamics of phreatic water chemistry in the region relatively more complex. Although the groundwater quality in the Yinchuan Plain has been assessed by many researchers in the past [5,6], there is little knowledge about the groundwater quality status of the Yinchuan Plain after the significant reduction in water transfer from the Yellow River. Inadequate information on the effects of the natural and anthropogenic factors on water quality greatly impede the sustainable utilization of groundwater in the area. In this context, to build a new and sustainable Silk Road Economic Belt, it is necessary to assess the current groundwater quality and identify the hydrogeochemical processes contributing to the chemical compositions in the groundwater.

The suitability of irrigation waters can be evaluated by salinity and sodium hazard indicators. The USDA (United States Department of Agriculture) method is widely recognized, and sodium absorption ratio (SAR) is an effective index for irrigation water [7]. Other metrics including residual sodium carbonate (RSC), sodium percentage (Na\%), permeability index (PI) and magnesium hazard $(\mathrm{MH})$, can provide further information on the suitability of groundwater for agricultural irrigation [8]. Additionally, the water quality index (WQI) is an efficient method for water quality assessment by integrating various water quality parameters, which is widely used by many researchers to ascertain the situation of water quality. Chemical compositions in groundwater mainly depend on both the natural processes occurring in aquifers (such as lithology, residence time, geochemical reactions, etc.) and anthropogenic activities (such as agriculture, industry, etc.). Groundwater chemistry is strongly modified by the dissolution/precipitation of carbonate and evaporite minerals [9]. Apart from the processes of mineralization, the chemical elements are often affected by ion exchange, which noticeably modifies the contents of major cations [10,11]. The ionic ratios, saturation indices and Gibbs diagrams are frequently performed to identify the main geochemical processes responsible for evolution of groundwater chemistry $[8,12]$. The deterioration of groundwater quality becomes an important worldwide issue, which may pose a serious threat to human health, food security and economic development. Thus, it is imperative to pay much more attention to understanding the hydrochemical characteristics and groundwater quality for the sustainable management of groundwater resources.

This study aimed to gain a comprehensive understanding of the current situation of groundwater quality and the main factors altering the water quality, with the significant reduction in water transfer from the Yellow River. The specific objectives were to (1) evaluate the phreatic water quality status for drinking and irrigation purposes, and (2) identify the associated geochemical processes controlling the geochemical evolution of phreatic water in the study area. The findings will provide a comprehensive perspective of groundwater quality status for drinking and irrigation purposes, which would help decision makers address groundwater issues properly and formulate the sustainable management of groundwater resources in such irrigated regions along the upper Yellow River. 


\section{Study Area}

The study area $\left(38^{\circ} 10^{\prime}-38^{\circ} 20^{\prime} \mathrm{N}, 106^{\circ} 00^{\prime}-106^{\circ} 45^{\prime} \mathrm{E}\right)$ is located in the middle of the Yinchuan plain, Northwestern China, near the upper reaches of the Yellow River (Figure 1). The study area stretches $31-38 \mathrm{~km}$ wide from west to east and $20 \mathrm{~km}$ long from south to north, covering approximately $972 \mathrm{~km}^{2}$ (Figure 1). It is controlled by the continental arid to semi-arid climate, which is characterized by low rainfall and strong evaporation. According to meteorological data from 1971 to 2014, the average annual precipitation was $201.6 \mathrm{~mm}$, and the mean annual pan evaporation was $1851.7 \mathrm{~mm}$. The Yellow River runs through the study area from south to north. The Yinchuan Plain is one of China's most ancient Yellow River irrigation areas and has benefited a lot from the long history of irrigation from Yellow River. However, due to the huge gap of water supply in the lower Yellow River, the Yellow River Conservancy Commission has reduced the water transfer from the Yellow River [13]. With the reduction in water transfer from the Yellow River in Yinchuan Plain, groundwater resources will serve as an alternative to meet the demand of water supply.

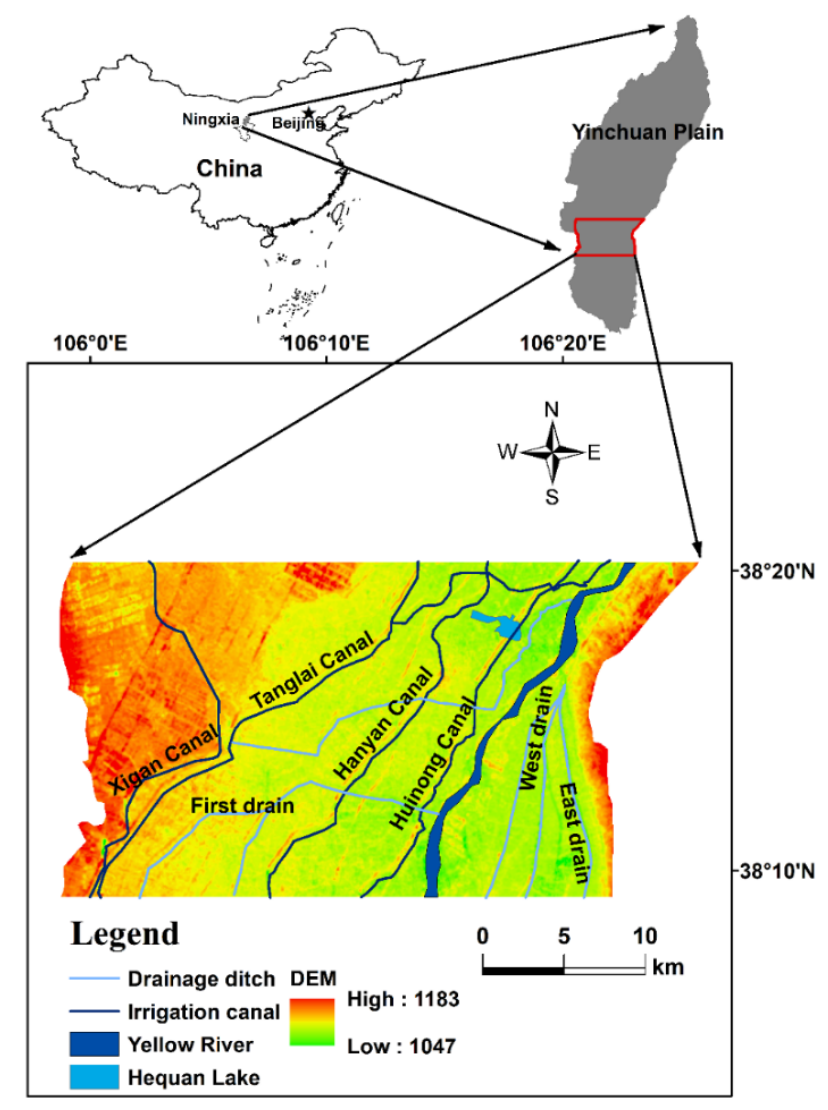

Figure 1. Geographic location of the study area.

The Quaternary sediments are well developed in the Yinchuan Plain with more than $2000 \mathrm{~m}$ in thickness [3]. Overall, calcite, dolomite, gypsum and halite are the primary mineral assemblages in the Quaternary sediments [14]. The topographical elevation of the study area is higher in the west and lower in the east, ranging from approximately 1047 to $1183 \mathrm{~m}$ above mean sea level. The main landforms in the study area are pluvial-alluvial plain of the Yellow River, and alluvial-lacustrine plain, respectively (Figure 2). The aquifer system in the study area can be divided into two types: phreatic aquifer and confined aquifer [15]. This study focuses on the phreatic aquifer, which is mainly composed of alluvial sands and gravels during the Quaternary. The movement of phreatic water is largely affected by topography, lithology, groundwater pumping, and spatial distribution of channels and ditches. The groundwater flows predominantly from the west to the northeast in general, but the 
runoff directions and runoff conditions have certain differences in various locations (Figure 2). Depth to water table in the domain is generally less than $5 \mathrm{~m}$. Hydraulic gradient is generally lower than $0.5 \%$ in the alluvial-pluvial plain and alluvial-lacustrine plain, suggesting that groundwater flows very slowly in this region (Figure 2).

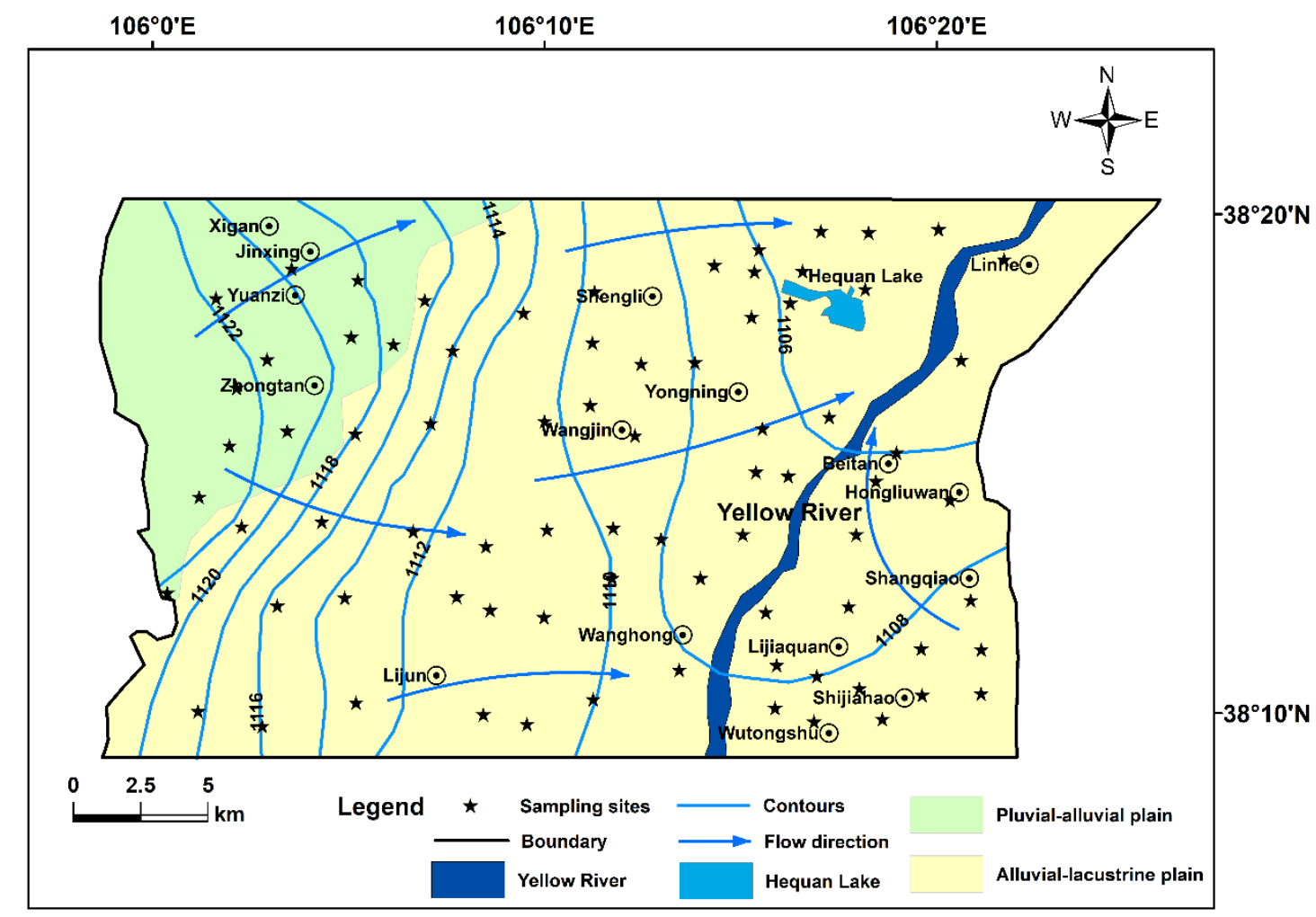

Figure 2. Hydrogeological map of phreatic aquifer and sampling stations in the study area.

More than $80 \%$ of the total groundwater recharge occurs mainly by the leakage of irrigation canals through pores in the Quaternary unconsolidated sediments, which consist mainly of fine sand, silty fine sand. Due to the groundwater's shallow depth, slow movement, and the lithology of the vadose zone, evaporation is the primary pattern of phreatic water discharge. Drainage ditches and artificial pumping are also important patterns of groundwater discharge. The hydro-environment system in this region is disturbed by a variety of human activities, such as agricultural irrigation, animal husbandry, fisheries, and groundwater pumping. Particularly, water diversion for irrigation from the Yellow River to the Yinchuan Plain has lasted for more than 2000 years. As a result, this long-term practice has elevated the water table and promoted more intensive evaporation and hence a higher concentration of ions in groundwater [16].

\section{Materials and Methods}

\subsection{Groundwater Sampling and Analytical Techniques}

In this study, 78 samples of phreatic water were collected in September 2018, during the summer-autumn irrigation period occurring annually from late April to late September. A portable GPS device was used to record the locations of samples (Figure 2). Most of the groundwater samples were taken from irrigation and domestic supply wells. Information on the use of the groundwater and the depth of the screen in the wells was acquired from the well administrator and farmers. The wells were pumped for several minutes to eliminate the influence of static water. All water samples were instantly stored at $4{ }^{\circ} \mathrm{C}$ in pre-cleaned polyethylene bottles with watertight caps until analysis. Sample 
collection, preservation, analytical procedures and the choice of pollutants followed the national guidelines recommended by the Chinese Ministry of Water Resources.

During the sampling campaign, $\mathrm{pH}$, water temperature and total dissolved solids (TDS) of each sample were measured in situ using a portable $\mathrm{pH} / \mathrm{TDS}$ meter, which was previously calibrated. Other chemical parameters were analyzed by Laboratory of Ningxia Geology and Mineral Resources Center. Bicarbonate $\left(\mathrm{HCO}_{3}{ }^{-}\right)$in each water sample was determined by the diluted vitriol-methylic titration method on the day of sampling. For the major cations and trace elements $\left(\mathrm{K}^{+}, \mathrm{Na}^{+}, \mathrm{Ca}^{2+}, \mathrm{Mg}^{2+}, \mathrm{Fe}, \mathrm{As}\right.$ and $\mathrm{Mn}$ ) were analyzed by inductively coupled plasma optical omission spectrometry with detection limits of $0.1 \mathrm{mg} / \mathrm{L}$ for cations and of $0.01 \mathrm{mg} / \mathrm{L}$ for $\mathrm{Fe}$, As and $\mathrm{Mn}$. The major anions including $\mathrm{Cl}^{-}$, $\mathrm{SO}_{4}{ }^{2-}, \mathrm{NO}_{3}{ }^{-}$and $\mathrm{F}^{-}$were measured by ion chromatography with detection limits of $0.04,0.1,0.04$ and $0.02 \mathrm{mg} / \mathrm{L}$, respectively. The errors of charge balance were calculated for the reliability of chemical data. The calculated results of the charge balance errors showed that the uncertainty was less than $\pm 5 \%$, which can be accepted in this study.

\subsection{Water Quality Index}

Water quality index (WQI) is an efficient tool in evaluating water quality for drinking purposes and water resources management. It is a quality evaluation criterion dependent on the assessment of various chemical elements, representing the effects of different chemical parameters on the overall quality of drinking water. These indices have been applied to water quality assessment worldwide, providing important implications of groundwater quality management for public and policymakers $[17,18]$.

Water quality index was calculated according to the following equation:

$$
\mathrm{WQI}=\sum\left[W_{i} \times\left(\frac{C_{i}}{S_{i}}\right) \times 100\right]
$$

where the relative weight $W_{i}=\frac{w_{i}}{\sum w_{i}}$, " $w_{i}$ " is the weight of each chemical parameter determined by its relative impacts on human health for drinking purposes [18]. " $C_{i}$ " is the observed concentration of each chemical element in each groundwater sample, and " $S_{i}$ " is the corresponding standard values [19] for each chemical parameter. In terms of the calculated WQI values, water quality can be divided into five different categories. The water quality is excellent when WQI $<50$; water quality is good when $50 \leq \mathrm{WQI}<100$; water quality is poor when $100 \leq \mathrm{WQI}<200$; water quality is very poor when $200 \leq \mathrm{WQI}<300$; if WQI $\geq 300$, groundwater is unsuitable for drinking purposes.

\subsection{Irrigation Water Quality Evaluation}

The irrigation water quality is determined by the chemical compositions in water and has significant impacts on the production of crops. Irrigation water of excellent quality combined with sustainable agricultural practices can maximize the yield of crops $[8,20]$. In this research, the quality of irrigation water was evaluated by sodium adsorption ratio (SAR), residual sodium carbonate (RSC), sodium percentage $(\mathrm{Na} \%)$, permeability index $(\mathrm{PI})$ and magnesium hazard $(\mathrm{MH})$. These parameters can be obtained by solving the following equations, where the concentrations of the cations were expressed in meq/L.

$$
\begin{gathered}
\mathrm{SAR}=\frac{\mathrm{Na}^{+}}{\sqrt{\frac{\left(\mathrm{Ca}^{2+}+\mathrm{Mg}^{2+}\right)}{2}}} \\
\mathrm{RSC}=\left(\mathrm{HCO}_{3}^{-}+\mathrm{CO}_{3}^{2-}\right)-\left(\mathrm{Ca}^{2+}+\mathrm{Mg}^{2+}\right) \\
\mathrm{Na} \%=\frac{\left(\mathrm{Na}^{+}+\mathrm{K}^{+}\right) * 100}{\left(\mathrm{Ca}^{2+}+\mathrm{Mg}^{2+}+\mathrm{Na}^{+}+\mathrm{K}^{+}\right)}
\end{gathered}
$$




$$
\begin{gathered}
\mathrm{PI}=\frac{\left(\mathrm{Na}^{+}+\sqrt{\mathrm{HCO}_{3}^{-}}\right) \times 100}{\left(\mathrm{Ca}^{2+}+\mathrm{Mg}^{2+}+\mathrm{Na}^{+}\right)} \\
\mathrm{MH}=\frac{\mathrm{Mg}^{2+}}{\mathrm{Ca}^{2+}+\mathrm{Mg}^{2+}} \times 100
\end{gathered}
$$

\section{Results and Discussion}

\subsection{Drinking Water Quality Assessment}

\subsubsection{Statistical Analysis of Chemical Parameters}

The statistical summary of chemical parameters of groundwater samples is shown in Table 1. To assess the suitability of groundwater samples, concentrations of chemical elements in the groundwater samples were compared with the recommended standards for drinking water [19].

Given that the $\mathrm{pH}$ varied from 7.3 to 8.1 with an average of 7.7 (Table 1), the phreatic water was slightly alkaline, which was probably ascribed to alkaline cations and bicarbonate in the groundwater. The $\mathrm{pH}$ values of all the samples were within the permissible limits (6.5-8.5) of WHO standards for drinking purposes [19].

TDS is a key parameter of potable water, and it is often considered to be a measure of water palatability. The total dissolved solids (TDS) changed from 272 to $5082 \mathrm{mg} / \mathrm{L}$ with a mean value of $1095 \mathrm{mg} / \mathrm{L}$ and a higher value $(912 \mathrm{mg} / \mathrm{L})$ of the standard deviation. The large amplitude of TDS shows significant differences in groundwater mineralization, which could be attributed to the joint effects of aquifer heterogeneity, variability in the geochemical processes, groundwater residence time and agricultural activities in the area. A total of $31 \%$ of the samples exceeded the acceptable limit (1000 mg/L) and showed unpalatable for human health, according to the WHO standards for TDS [19].

Hardness of water mainly refers to the existence of various dissolved calcium and magnesium [19]. The total hardness (TH) varied from 203 to $1396 \mathrm{mg} / \mathrm{L}$, with an average of $543 \mathrm{mg} / \mathrm{L}$ (Table 1). It should be noted that $54 \%$ of groundwater samples exceeded the permissible limit of $500 \mathrm{mg} / \mathrm{L}$. According to the classification of total hardness $(\mathrm{TH})$ proposed by Sawyer and McCarty [21], groundwater is classified into four categories, i.e., soft water (0-75 mg/L), moderately soft (76-150 mg/L), hard (151-300 mg/L) and very hard (> $300 \mathrm{mg} / \mathrm{L}$ ). Therefore, all the phreatic water samples fell in the categories of very hard water $(91 \%)$ and hard water $(9 \%)$ in the study area. 
Table 1. Statistics of chemical parameters and the parameters for water quality index (WQI) calculation in phreatic water.

\begin{tabular}{|c|c|c|c|c|c|c|c|}
\hline \multirow{2}{*}{ Chemical Parameters } & \multicolumn{4}{|c|}{ Groundwater } & \multicolumn{3}{|c|}{ Parameters for WQI Calculation } \\
\hline & Min. & Max. & Ave. & SD & WTO Standards & Weight $\left(w_{i}\right)$ & Relative Weight $\left(\mathrm{W}_{\mathrm{i}}\right)$ \\
\hline $\mathrm{pH}$ & 7.3 & 8.1 & 7.7 & 0.2 & $6.5-8.5$ & 4 & 0.0714 \\
\hline TDS $(\mathrm{mg} / \mathrm{L})$ & 272 & 5082 & 1095 & 912 & 1000 & 4 & 0.0714 \\
\hline $\mathrm{TH}(\mathrm{mg} / \mathrm{L})$ & 203 & 1396 & 543 & 236 & 500 & 4 & 0.0714 \\
\hline $\mathrm{K}^{+}(\mathrm{mg} / \mathrm{L})$ & 1.6 & 37.8 & 4.1 & 4.3 & 12 & 2 & 0.0357 \\
\hline $\mathrm{Na}^{+}(\mathrm{mg} / \mathrm{L})$ & 25.8 & 1258.0 & 178.9 & 239.1 & 200 & 3 & 0.0536 \\
\hline $\mathrm{Ca}^{2+}(\mathrm{mg} / \mathrm{L})$ & 17.0 & 217.5 & 100.4 & 42.5 & 200 & 2 & 0.0357 \\
\hline $\mathrm{Mg}^{2+}(\mathrm{mg} / \mathrm{L})$ & 23.6 & 211.4 & 70.9 & 37.2 & 150 & 2 & 0.0357 \\
\hline $\mathrm{Cl}^{-}(\mathrm{mg} / \mathrm{L})$ & 36.2 & 1930.0 & 210.8 & 333.9 & 250 & 4 & 0.0714 \\
\hline $\mathrm{SO}_{4}{ }^{2-}(\mathrm{mg} / \mathrm{L})$ & 49.7 & 1475.0 & 274.1 & 257.8 & 250 & 5 & 0.0893 \\
\hline $\mathrm{HCO}_{3}{ }^{-}(\mathrm{mg} / \mathrm{L})$ & 155.3 & 724.7 & 416.6 & 150.1 & 600 & 3 & 0.0536 \\
\hline $\mathrm{NO}_{3}{ }^{-}(\mathrm{mg} / \mathrm{L})$ & 0.5 & 315.3 & 31.0 & 57.6 & 50 & 5 & 0.0893 \\
\hline $\mathrm{F}^{-}(\mathrm{mg} / \mathrm{L})$ & 0.1 & 1.8 & 0.6 & 0.3 & 1.5 & 5 & 0.0893 \\
\hline $\mathrm{Fe}(\mathrm{mg} / \mathrm{L})$ & 0.0 & 6.5 & 1.0 & 1.8 & 0.3 & 4 & 0.0714 \\
\hline As $(\mu \mathrm{g} / \mathrm{L})$ & 0.1 & 22.4 & 2.7 & 4.8 & 10 & 5 & 0.0893 \\
\hline $\mathrm{Mn}(\mu \mathrm{g} / \mathrm{L})$ & 1.0 & 707.0 & 177.9 & 193.8 & 100 & 4 & 0.0714 \\
\hline
\end{tabular}


Results of chemical analysis showed that the mean concentration of the major cations followed the trend $\mathrm{Na}^{+}>\mathrm{Ca}^{2+}>\mathrm{Mg}^{2+}>\mathrm{K}^{+}$, while in case of anions, the order was $\mathrm{HCO}_{3}{ }^{-}>\mathrm{SO}_{4}{ }^{2-}>\mathrm{Cl}^{-}>\mathrm{NO}_{3}{ }^{-}$. The concentrations of $\mathrm{Na}^{+}$and $\mathrm{K}^{+}$were in the range of $25.8-1258.0 \mathrm{mg} / \mathrm{L}$ and $1.6-37.8 \mathrm{mg} / \mathrm{L}$, with averages of 178.9 and $4.1 \mathrm{mg} / \mathrm{L}$, respectively. Fifteen samples had high contents of $\mathrm{Na}^{+}(>200 \mathrm{mg} / \mathrm{L})$ exceeding the permissible limit of the WHO standard. Excessive $\mathrm{Na}^{+}$above the maximum permissible limit can cause adverse health risks such as hypertension and vomiting $[19,22]$. The concentration of $\mathrm{K}^{+}$ in groundwater was generally quite lower than $\mathrm{Ca}^{2+}, \mathrm{Mg}^{2+}, \mathrm{Na}^{+}$. Only two samples had high levels of $\mathrm{K}^{+}$above the acceptable limit of WHO $(>12 \mathrm{mg} / \mathrm{L}) . \mathrm{Ca}^{2+}$ and $\mathrm{Mg}^{2+}$ are indispensable to maintain human health. Lack of calcium in drinking water can cause some diseases such as osteoporosis, hypertension, stroke, etc. [19]. In this study, the concentration of $\mathrm{Ca}^{2+}$ varied from 17.0 to $217.5 \mathrm{mg} / \mathrm{L}$ with a mean of $100.4 \mathrm{mg} / \mathrm{L}$. Only five samples were found to exceed the maximum allowable limit of $200 \mathrm{mg} / \mathrm{L}$ for drinking purposes [19]. The $\mathrm{Mg}^{2+}$ concentration changed from 23.6 to $211.4 \mathrm{mg} / \mathrm{L}$ with an average of $70.9 \mathrm{mg} / \mathrm{L}$. A total of $96 \%$ of samples were within the acceptable limit of $\mathrm{Mg}^{2+}(150 \mathrm{mg} / \mathrm{L})$ [19]. With respect to anions, alkalinity $\left(\mathrm{HCO}_{3}{ }^{-}\right)$predominated in the groundwater samples and changed from 155.3 to $724.7 \mathrm{mg} / \mathrm{L}$ with averaging $416.6 \mathrm{mg} / \mathrm{L}$. The majority of bicarbonate $(90 \%)$ fell within the maximum permissible limit based on the WHO standard $(600 \mathrm{mg} / \mathrm{L})$. The $\mathrm{SO}_{4}{ }^{2-}$ concentration ranged from 49.7 to $1475.0 \mathrm{mg} / \mathrm{L}$ with a mean of $274.1 \mathrm{mg} / \mathrm{L}$ (Table 1). Almost $28 \%$ of the samples were above the upper limit of $\mathrm{SO}_{4}{ }^{2-}(250 \mathrm{mg} / \mathrm{L})$ for drinking water that recommended by WHO and Chinese standards. High level of $\mathrm{SO}_{4}{ }^{2-}$ may cause a laxative effect on human system with the excessive $\mathrm{Mg}^{2+}$ in drinking water [6]. $\mathrm{Cl}^{-}$is generally considered to be a conservative element in water and an indicator of contamination. Excessive $\mathrm{Cl}^{-}$concentration in water usually creates a salty taste, and might have a laxative effect. The permissive limit of $\mathrm{Cl}^{-}$in drinking water is $250 \mathrm{mg} / \mathrm{L}$ according to the WHO standards. In this study, chloride concentration ranged from 36.2 to $1930.0 \mathrm{mg} / \mathrm{L}$, with an average of $210.8 \mathrm{mg} / \mathrm{L}$ (Table 1 ). Most of the groundwater samples ( $85 \%$ ) were suitable for drinking, but 12 samples had high contents of $\mathrm{Cl}^{-}$exceeding the permissible limit. The unusual increment in $\mathrm{Cl}^{-}$concentration is probably linked to the joint effect of both halite dissolution and anthropogenic pollution.

Nitrate contamination in phreatic water has been a growing concern to hydrogeologists and practitioners over the world $[22,23]$. In the study area, a large quantity of chemical fertilizers were used by farmers to ensure better crop yields because agricultural cultivation is usually the principal economic source for local residents. The $\mathrm{NO}_{3}{ }^{-}$concentration varied from 0.5 to $315.3 \mathrm{mg} / \mathrm{L}$ with an average of $31.0 \mathrm{mg} / \mathrm{L}$, and almost $19 \%$ samples were obviously much higher than the WHO standard $(50 \mathrm{mg} / \mathrm{L})$ for drinking water [19]. The nitrate in the groundwater mainly derives from anthropogenic practices such as nitrogen fertilizers, domestic effluents, animal waste and leakage of septic tanks, etc. As per classification nitrate [22], six samples belong to high risk and nine samples come under very high health risk category.

Additionally, some trace elements are essential for human health, but their long-term accumulation in groundwater may also pose potential threats to ecological security and human health [24]. In this study, some trace elements ( $\left.\mathrm{F}^{-}, \mathrm{Fe}, \mathrm{As}, \mathrm{Mn}\right)$ will be considered in the assessment of water quality given that the concentrations of other trace elements were negligible. The $\mathrm{F}^{-}$concentration varied from 0.1 to $1.8 \mathrm{mg} / \mathrm{L}$ with a mean of $0.6 \mathrm{mg} / \mathrm{L}$. Four samples showed high levels of fluoride above the acceptable limit $(1.5 \mathrm{mg} / \mathrm{L})$ in accordance with the WTO standard [19]. Fe is one of the main trace elements in groundwater. In the study area, the concentration of Fe was in the range of $0-6.5 \mathrm{mg} / \mathrm{L}$, with an average of $1.0 \mathrm{mg} / \mathrm{L}$. A total of $36 \%$ of the samples had high contents of Fe exceeding the permissible limit $(0.3 \mathrm{mg} / \mathrm{L})$ [19]. In China, about 15 million people have been affected by high As concentration $(>10 \mu \mathrm{g} / \mathrm{L})$, especially in northwestern China [25]. Given that groundwater is used for both drinking and irrigation purposes in this region, As concentrations in the groundwater would not only affect the quality of crops, but also deteriorate drinking water quality. Drinking groundwater with high As concentration for a long time may cause potentially carcinogenic effects, diabetes, hypertension, neuropathy, etc. [26]. As concentration changed from 0.1 to $22.4 \mu \mathrm{g} / \mathrm{L}$, with a mean of $2.7 \mu \mathrm{g} / \mathrm{L}$. Four samples had high levels of As beyond the prescribed limit $(10 \mu \mathrm{g} / \mathrm{L})$ [19]. The concentration of Mn 
varied from 1.0 to $707.0 \mu \mathrm{g} / \mathrm{L}$, with an average of $177.9 \mu \mathrm{g} / \mathrm{L}$. Half of the samples had higher contents of Mn above the WHO standard (100 $\mu \mathrm{g} / \mathrm{L})$ for drinking water [19].

\subsubsection{Spatial Distribution of Major Chemical Parameters}

To understand the current situation of groundwater quality and identify the spatial patterns of chemical elements, the technique of the inverse distance weighted (IDW) interpolation was used to map the spatial distribution of the main chemical indicators of groundwater quality (TDS, $\mathrm{Na}^{+}, \mathrm{SO}_{4}{ }^{2-}$, $\mathrm{Cl}^{-}, \mathrm{NO}_{3}{ }^{-}, \mathrm{Mn}$ ) in ArcGIS 10.1 software.

It is clear that the TDS values increased progressively from west to east (Figure 3a). The phreatic water with TDS less than $1000 \mathrm{mg} / \mathrm{L}$ was mainly distributed on the west bank of the Yellow River. However, on the east bank of the Yellow River, the TDS values of phreatic water were generally higher than $1000 \mathrm{mg} / \mathrm{L}$ and were even larger than $2000 \mathrm{mg} / \mathrm{L}$ in some areas such as Shijiahao, Wutongshu, Shangqiao, Hongliuwan, and Beitan. In terms of TDS, the phreatic water quality on the west bank of the Yellow River is considered to be better than that on the east bank of the Yellow River.
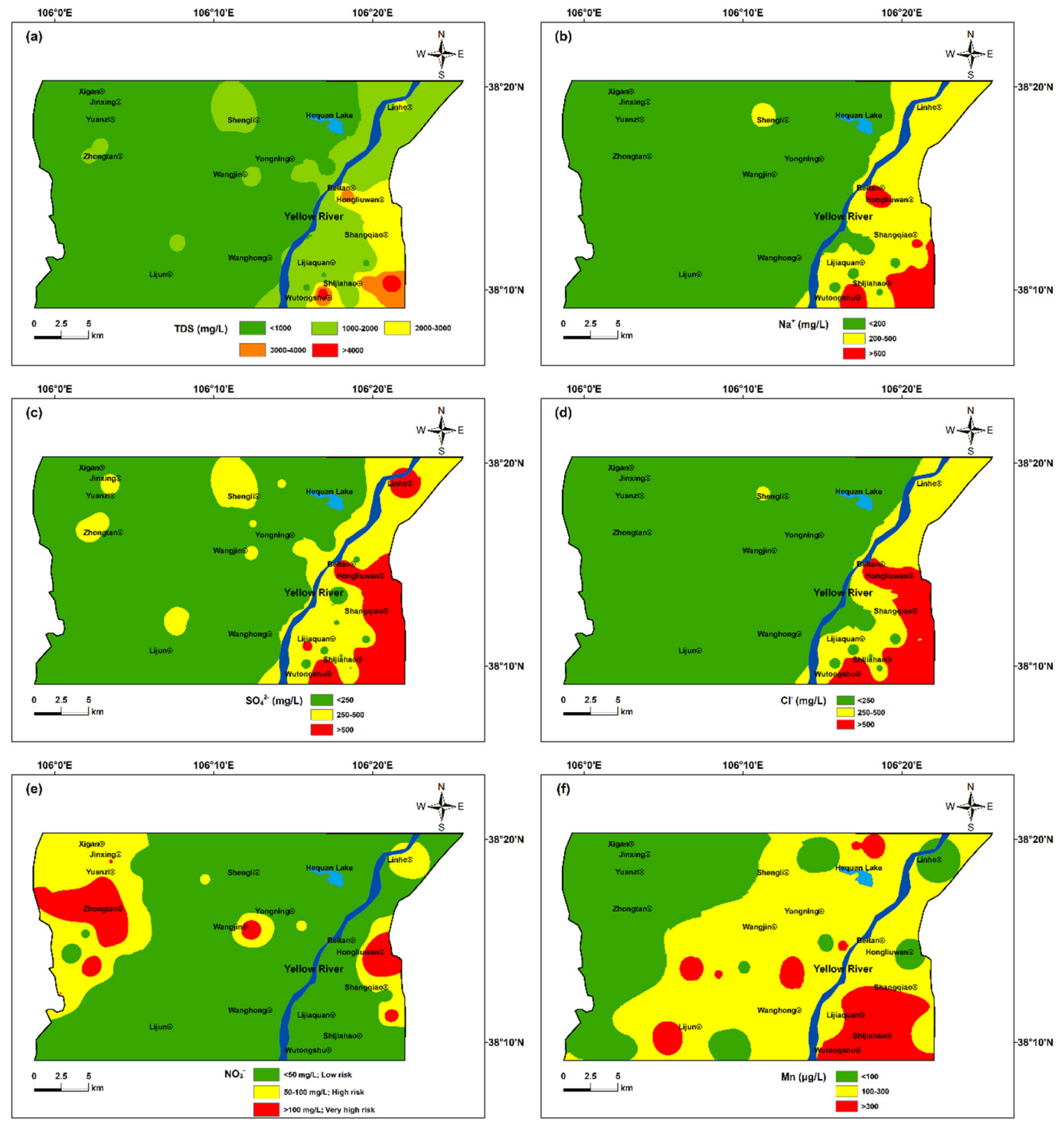

Figure 3. Spatial distribution of (a) Total dissolved solid (TDS), (b) $\mathrm{Na}^{+}$, (c) $\mathrm{SO}_{4}{ }^{2-}$, (d) $\mathrm{Cl}^{-},(\mathbf{e}) \mathrm{NO}_{3}{ }^{-}$ and (f) $\mathrm{Mn}$ in the study area. 
The concentration of $\mathrm{Na}^{+}$shows a similar pattern to TDS (Figure 3b). West of the Yellow River, the $\mathrm{Na}^{+}$concentration in the phreatic aquifer was lower than $200 \mathrm{mg} / \mathrm{L}$, while the high level of $\mathrm{Na}^{+}$ ( $>200 \mathrm{mg} / \mathrm{L}$ ) can be observed in most areas east of the Yellow River. Especially, the $\mathrm{Na}^{+}$concentration of phreatic water in some villages (Shijiahao, Wutongshu, and Beitan) was even larger than $500 \mathrm{mg} / \mathrm{L}$.

Analogous to the spatial pattern of $\mathrm{Na}^{+}$, the phreatic water on both banks of the Yellow River shows significant difference in the concentrations of $\mathrm{SO}_{4}{ }^{2-}$ and $\mathrm{Cl}^{-}$(Figure $3 \mathrm{c}, \mathrm{d}$ ). The concentrations of $\mathrm{SO}_{4}{ }^{2-}$ and $\mathrm{Cl}^{-}$in most parts west of the Yellow River were generally lower than the WTO standard $(250 \mathrm{mg} / \mathrm{L})$ for drinking water [19]. However, in some rural areas (Beitan, Hongliuwan, Shangqiao, Shijiahao, and Wutongshu), phreatic water showed very high levels of $\mathrm{SO}_{4}{ }^{2-}$ and $\mathrm{Cl}^{-}$, greater than $500 \mathrm{mg} / \mathrm{L}$.

With respect to the spatial distribution of nitrate in the study area (Figure 3e), high and very high risk areas were mostly observed in the villages of Zhongtan, Wangjin, and Hongliuwan. Particularly, it should be noted that the pluvial-alluvial plain in the study area was facing the serious problem of the nitrate contamination (Figures 2 and 3e). The fine-grained zone in the intermediate area between mountain-front areas and Yinchuan plain, varies greatly in hydraulic properties, which probably contributes to the nitrate enrichment in the pluvial-alluvial plain. As a rule, fine-grained zone with low permeability often become storage space of pollutants, where groundwater samples have high concentration of contaminants. Therefore, apart from anthropogenic input, the fine-grained zone also plays a key role in the formation of nitrate pollution in pluvial-alluvial plain.

The spatial distribution of Mn shows a different pattern from other indicators for water quality (Figure 3f). Phreatic water only showed the concentration of Mn less than $100 \mu \mathrm{g} / \mathrm{L}$ in a few areas, mainly distributed in the pluvial-alluvial plain. However, in most central and eastern regions, the concentration of Mn was generally larger than the WHO standard $(100 \mu \mathrm{g} / \mathrm{L})$ for drinking water [19]. It is noteworthy that the Mn concentration was even greater than $300 \mu \mathrm{g} / \mathrm{L}$ in southeastern areas including the villages of Lijiaquan, Shijiahao, and Wutongshu.

\subsubsection{Water Quality Index (WQI)}

Water quality index (WQI) was applied to evaluate the current status of groundwater quality for drinking purposes in the study area. The weight of each chemical parameter ranged from 2 to 5 , dependent upon its relative importance in deteriorating the water quality for domestic use (Table 1). Results of the current study illustrated that water quality index (WQI) ranged from 22 to 367 with an average of 78. Phreatic water samples were generally "excellent" $(40 \%)$ and "good" $(41 \%)$ in the irrigated Region. In total, 9 samples (12\%) and 3 samples (4\%) were categorized as poor and very poor quality type, respectively. A total of 3 samples ( $4 \%$ ) were considered to be unsuitable for drinking water.

Spatial distribution of WQI in phreatic water is illustrated in Figure 4. It is apparent that the phreatic water was excellent or good in most areas west of the Yellow River. In contrast, east of the Yellow River, the poor water quality samples with high WQI values can be observed in most regions. The groundwater with very poor water quality occurred in some villages such as Hongliuwan and Beitan, and even the phreatic water in the village of Shijiahao was unsuitable for drinking water.

By a comparison of spatial patterns of WQI and major chemical indicators (Figures 3 and 4), the information on what is controlling the observed WQI values can be obtained. It is clear that the spatial distribution of WQI is analogous to those of TDS, $\mathrm{Na}^{+}, \mathrm{SO}_{4}{ }^{2-}$ and $\mathrm{Cl}^{-}$, suggesting that such chemical parameters were mainly responsible for the observed WQI values. However, although the nitrate was assigned the highest relative weight, it does not appear to be a primary driver of the WQI values. In some areas, the high $\mathrm{NO}_{3}{ }^{-}$values were observed in phreatic water (Figure 3e), but such areas showed the low WQI values (Figure 4). Additionally, a significant difference in spatial patterns of WQI and Mn, suggests that Mn contributed little to the observed WQI values. 


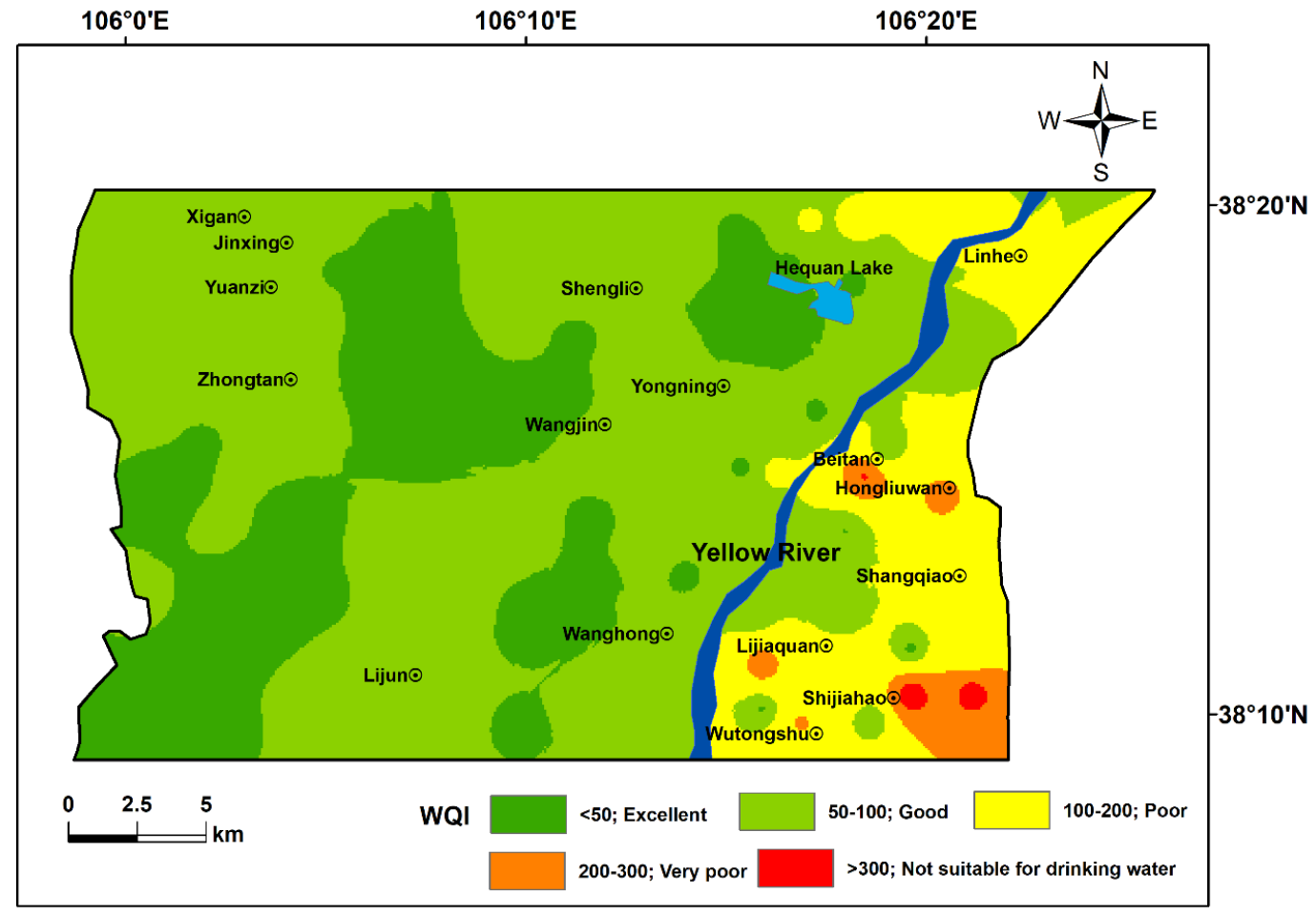

Figure 4. Spatial distribution of WQI in the study area.

\subsection{Irrigation Water Quality Assessment}

Table 2 presents the statistical results of these indices for irrigation water quality assessment, including sodium adsorption ratio (SAR), residual sodium carbonate (RSC), sodium percentage $(\mathrm{Na} \%)$, permeability index (PI), and magnesium hazard (MH).

Table 2. Calculated irrigation quality indices for phreatic water in the study area.

\begin{tabular}{ccccc}
\hline Parameters & Min. & Max. & Mean & Std \\
\hline SAR & 0.78 & 14.89 & 2.97 & 2.87 \\
RSC & -22.38 & 2.36 & -4.10 & 4.19 \\
Na $\%$ & 18.56 & 67.06 & 34.98 & 12.33 \\
PI & 37.25 & 77.26 & 51.93 & 9.35 \\
MH & 31.97 & 90.60 & 53.13 & 10.01 \\
\hline
\end{tabular}

The sodium adsorption ratio (SAR) generally represents the sodium/alkali hazard. The soil texture in the irrigated region probably becomes too hard to plough, because of the long-term application of irrigation water with high sodium levels [27]. The SAR values in the study area varied from 0.78 to 14.89 with a mean of 2.97. As per Richards [7] classification, $95 \%$ of the groundwater samples fell under the excellent category for irrigation, while $5 \%$ of the samples are good for irrigation (Table 3).

The US salinity diagram can be also employed to the classification of irrigation water quality [7] (Figure 5a). Only two water samples fall in the category C2-S1 (medium salinity and low sodium), indicating that such water can be applied to irrigate the moderate salt-tolerant crops. However, $74 \%$ of the groundwater samples are distributed in the domain of C3-S1 (high salinity and low SAR), suggesting that most of phreatic water samples are unsuitable for irrigation on the soils with limited drainage. A few water samples belong to the categories C3-S2, C4-S1, C4-S2, and C4-S3 with very high salinity and high sodium hazard. 
Table 3. Groundwater quality classification for irrigation purposes.

\begin{tabular}{cccc}
\hline Parameters & Range & Classification & Number of Samples \\
\hline Sodium hazard (SAR) & $<10$ & Excellent & 74 \\
& $10-18$ & Good & 4 \\
& $18-26$ & Doubtful & 0 \\
Residual sodium carbonate (RSC) & $>26$ & Unsuitable & 0 \\
& $<1.25$ & Suitable & 75 \\
Sodium percentage (Na\%) & $1.25-2.5$ & Marginally suitable & 3 \\
& $>2.5$ & Unsuitable & 0 \\
& $<20$ & Excellent & 2 \\
& $20-40$ & Good & 55 \\
& $40-60$ & Permissible & 15 \\
Permeability index (PI) & $60-80$ & Doubtful & 6 \\
& $>80$ & Unsuitable & 0 \\
& $>75$ & Good & 1 \\
Magnesium hazard (MH) & $25-75$ & Permissible & 77 \\
& $<25$ & Unsuitable & 0 \\
& $<50 \%$ & Suitable & 30 \\
& $>50 \%$ & Unsuitable & 48 \\
\hline
\end{tabular}
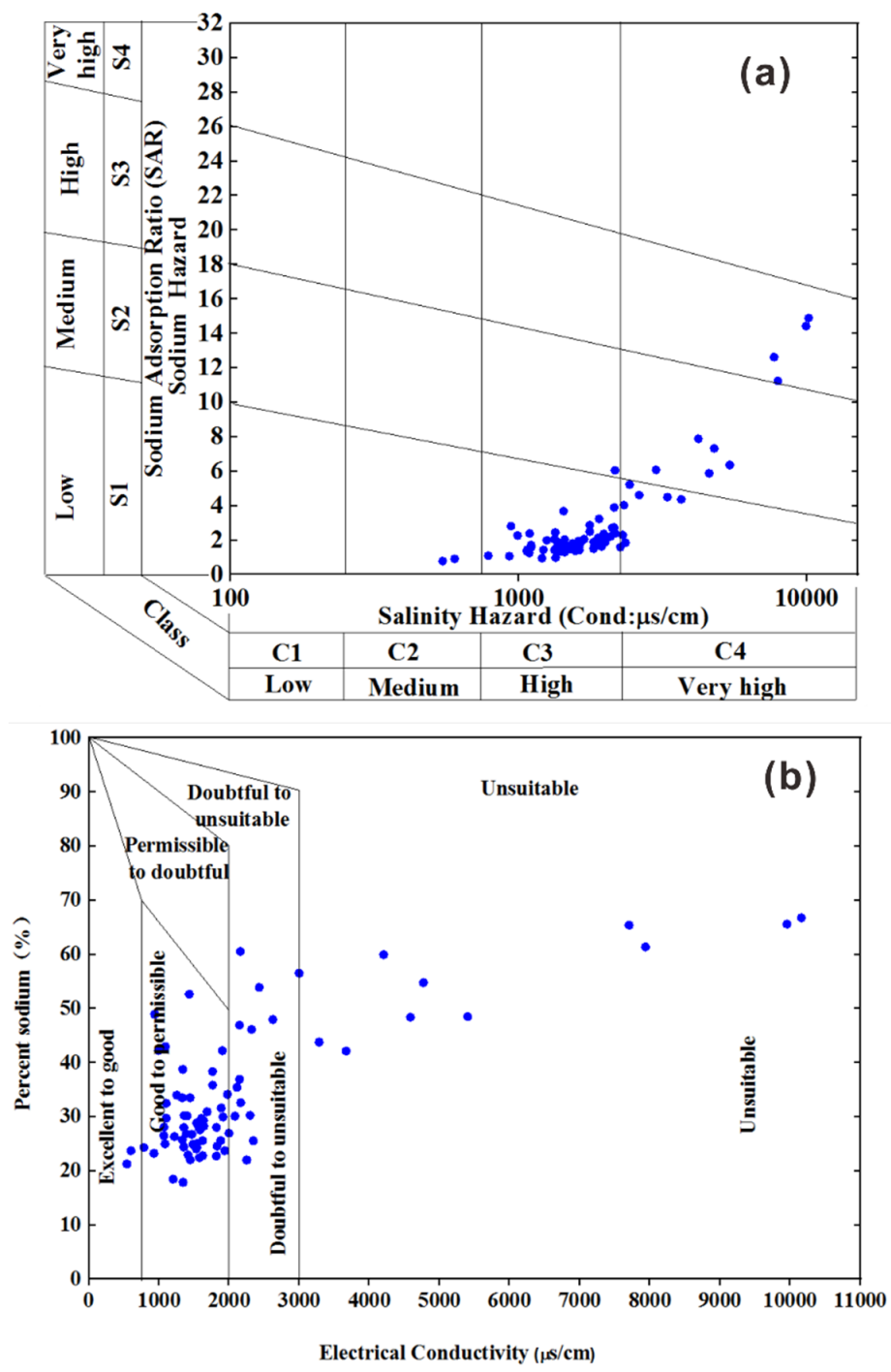

Figure 5. Diagram for irrigation waters classification (a), and plot of sodium percentage vs. electrical conductivity (b). 
Residual sodium carbonate ratio (RSC) given by Eaton [28], is effective in identifying the suitability of groundwater for irrigation through carbonate and bicarbonate ratio [29]. The phreatic water samples were classified according to the RSC classification criteria (Table 3) and the RSC value $<1.25$ is considered to be suitable for irrigation purposes. The results showed that RSC varied from -22.38 to 2.36 with an average of -4.10 (Table 2), which confirmed that groundwater in the study area was safe for irrigation use.

Sodium percentage (\%) varied from 18.56 to 67.06 , with a mean of $34.98 \%$. The groundwater was classified according to the standard classification of $\mathrm{Na}^{+}(\%)$ (Table 3) [17,30]. A total of 71\% of the groundwater samples belong to the category of "Good", while $27 \%$ of the samples fall in "permissible" to "doubtful" category. The reasons for a few samples with high sodium percentage might be the joint effects of lithological sources and the application of chemical fertilizers in agricultural activities. The groundwater samples were grouped into four categories, according to the plot of sodium percentage versus electrical conductivity (Figure 5b). Two samples belong to the category of "excellent to good" for irrigation, and $68 \%$ samples are grouped as "good to permissible" type. A total of 13 samples fall in the category of "doubtful to unsuitable", and 10 samples are unsuitable for irrigation. High concentration of sodium in water can decrease soil permeability and retard plant growth [17].

Long-term use of saline water for irrigation can exert significant effects on the soil permeability [31]. As a result, soil becomes very hard to plough and the growth of vegetation is retarded. Results showed that PI values ranged from 37.25 to 77.26 with a mean of 51.93 (Table 2). The classification of water quality in terms of permeability index was given by Doneen [32] (Table 3). Therefore, the phreatic water in this region was suitable for irrigation, which is in line with other studies [33].

Magnesium hazard (MH) is another measure of water quality assessment. Sometimes, an excess of $\mathrm{Mg}^{2+}$ may disrupt the equilibrium between $\mathrm{Ca}^{2+}$ and $\mathrm{Mg}^{2+}$, which would have negative effects on the growth of crops. If $\mathrm{MH}$ is greater than $50 \%$, it is unsuitable for irrigation use. The high loads of $\mathrm{Mg}^{2+}$ in water not only retards the capacity of soil infiltration by damaging soil structure, but also degrades the yield of crops by increasing the alkalinity of water [8]. The $\mathrm{MH}$ values varied from 31.97 to 90.60 with an average of 53.13. According to the water quality classification (Table 3) in terms of magnesium hazard, almost $62 \%$ of the water samples were unsuitable for agricultural irrigation. In a word, more than half of the phreatic water samples had magnesium hazard and were undesirable for irrigation. The results are consistent with other studies reported in some developing countries [17,33].

\subsection{Hydrochemical Facies}

Total dissolved solid (TDS) is an important index indicating the degree of groundwater mineralization. Generally, natural factors (topography, lithology, hydrogeological conditions) and anthropogenic activities jointly affect the change in TDS values by modifying the chemical compositions in water. In terms of groundwater mineralization, groundwater can be classified as three groups, namely, fresh groundwater (TDS $<1 \mathrm{~g} / \mathrm{L})$, moderately saline water $(1<\mathrm{TDS}<3 \mathrm{~g} / \mathrm{L})$ and saline water (TDS $>3 \mathrm{~g} / \mathrm{L}$ ) [14].

Generally, the fresh water is characterized by the predominance of bicarbonate, while chloride and sulfate prevail in saline water. Figure 6 shows a Piper triangular diagram identifying the major chemical facies and evolutionary trend of water samples [34]. With respect to cations, the majority of the points are scattered in zone B of the lower left triangle, indicating that there is no dominant cations in the phreatic water. For anions, most water samples are distributed in zones $\mathrm{E}$ and $\mathrm{B}$ of the lower right triangle, showing that some are bicarbonate type, some are no dominant type (Figure 6). A few samples belong to chloride type. The central diamond plot can provide valuable information that can differentiate between separate groups of samples. It is clear that most water samples are plotted in zone 1, showing that the alkaline earths predominate the chemical components of groundwater. As shown in Figure 3a, fresh waters with TDS $<1 \mathrm{~g} / \mathrm{L}$ are mainly distributed on the west bank of the Yellow River, and the hydrochemical facies are $\mathrm{Ca}-\mathrm{Mg}-\mathrm{HCO}_{3}, \mathrm{Ca}-\mathrm{Mg}-\mathrm{HCO}_{3}-\mathrm{SO}_{4}, \mathrm{Mg}-\mathrm{Na}-\mathrm{HCO}_{3}$, and $\mathrm{Mg}-\mathrm{Na}-\mathrm{HCO}_{3}-\mathrm{SO}_{4}$. However, the moderately saline water and the saline water are mainly observed 
on the east bank of the Yellow River. For moderately saline waters, the chemical facies are mainly $\mathrm{Na}-\mathrm{Ca}-\mathrm{HCO}_{3}-\mathrm{SO}_{4}$ and $\mathrm{Na}-\mathrm{Mg}-\mathrm{SO}_{4}-\mathrm{Cl}$. For water samples with TDS $>3 \mathrm{~g} / \mathrm{L}$, the phreatic water belongs to $\mathrm{Na}-\mathrm{Cl}-\mathrm{SO}_{4}$ type. The overall evolutionary trend of groundwater shows the transition of Ca-Mg- $\mathrm{HCO}_{3}$ type into Na-Cl-SO 4 type by a gradual enrichment of the $\mathrm{SO}_{4}{ }^{2-}$ and $\mathrm{Cl}^{-}$concentrations (Figure 6). Given the shallow water table, evaporation may be an important contributor for the elevated levels of $\mathrm{SO}_{4}{ }^{2-}$ and $\mathrm{Cl}^{-}$.

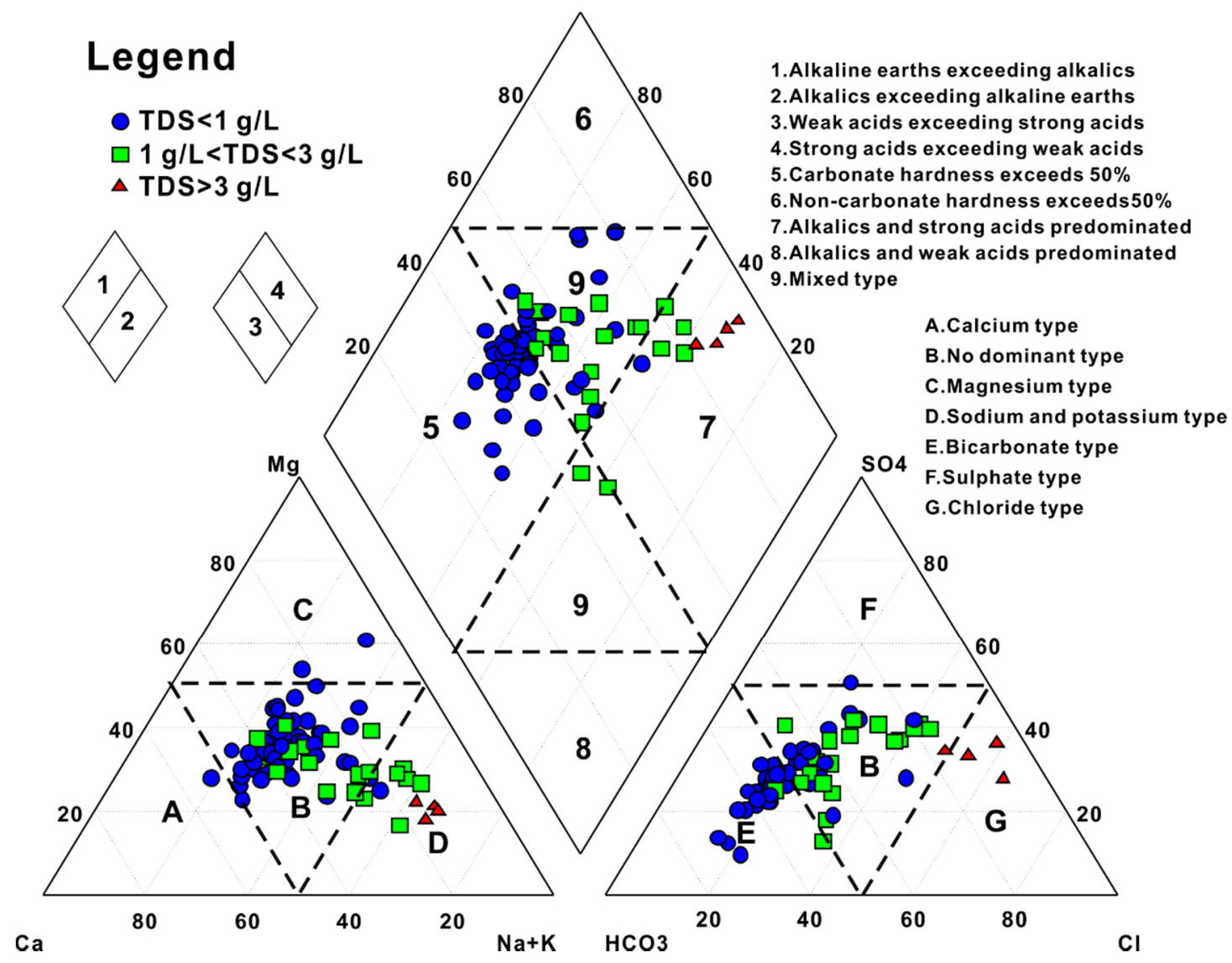

Figure 6. Piper diagram for water samples to determine the predominant water facies.

\subsection{Water-Rock Interaction}

Bicarbonate and Calcium in groundwater are mainly derived from the weathering of carbonate minerals [35]. The chemical reactions of calcite and dolomite illuminate the ratios of dissolved ions (Equations (7) and (8)). The molar $\mathrm{HCO}_{3}{ }^{-} / \mathrm{Ca}^{2+}$ ratio will be 2 if the groundwater is solely influenced by calcite dissolution, while the ratio will become 4 when both $\mathrm{Ca}^{2+}$ and $\mathrm{HCO}_{3}{ }^{-}$are only derived from dolomite dissolution. Three zones can be divided by dissolution lines of carbonate minerals (Figure 7a). It is clear that the majority of samples are scattered in the middle transitional area of both two lines where calcite and dolomite probably both dissolve. Only a few samples are projected to the lower zone, suggesting an excess of $\mathrm{Ca}^{2+}$. The surplus of $\mathrm{Ca}^{2+}$ may be attributed to the dissolution of gypsum, reverse ion exchange, or anthropogenic inputs. On the other hand, cation exchange depleting $\mathrm{Ca}^{2+}$ may be responsible for some samples plotting in the higher zone. Figure $7 \mathrm{~b}$ shows further evidence that dedolomitization contributed a lot to groundwater. The excess of $\mathrm{Mg}^{2+}$ may be ascribed to reverse ion exchange and anthropogenic sources such as fertilizers containing $\mathrm{Mg}^{2+}$.

$$
\begin{gathered}
\mathrm{CaCO}_{3}+\mathrm{CO}_{2}+\mathrm{H}_{2} \mathrm{O} \Leftrightarrow \mathrm{Ca}^{2+}+2 \mathrm{HCO}_{3}{ }^{-} \\
\mathrm{CaMg}\left(\mathrm{CO}_{3}\right)_{2}+2 \mathrm{CO}_{2}+2 \mathrm{H}_{2} \mathrm{O} \Leftrightarrow \mathrm{Ca}^{2+}+\mathrm{Mg}^{2+}+4 \mathrm{HCO}_{3}{ }^{-}
\end{gathered}
$$




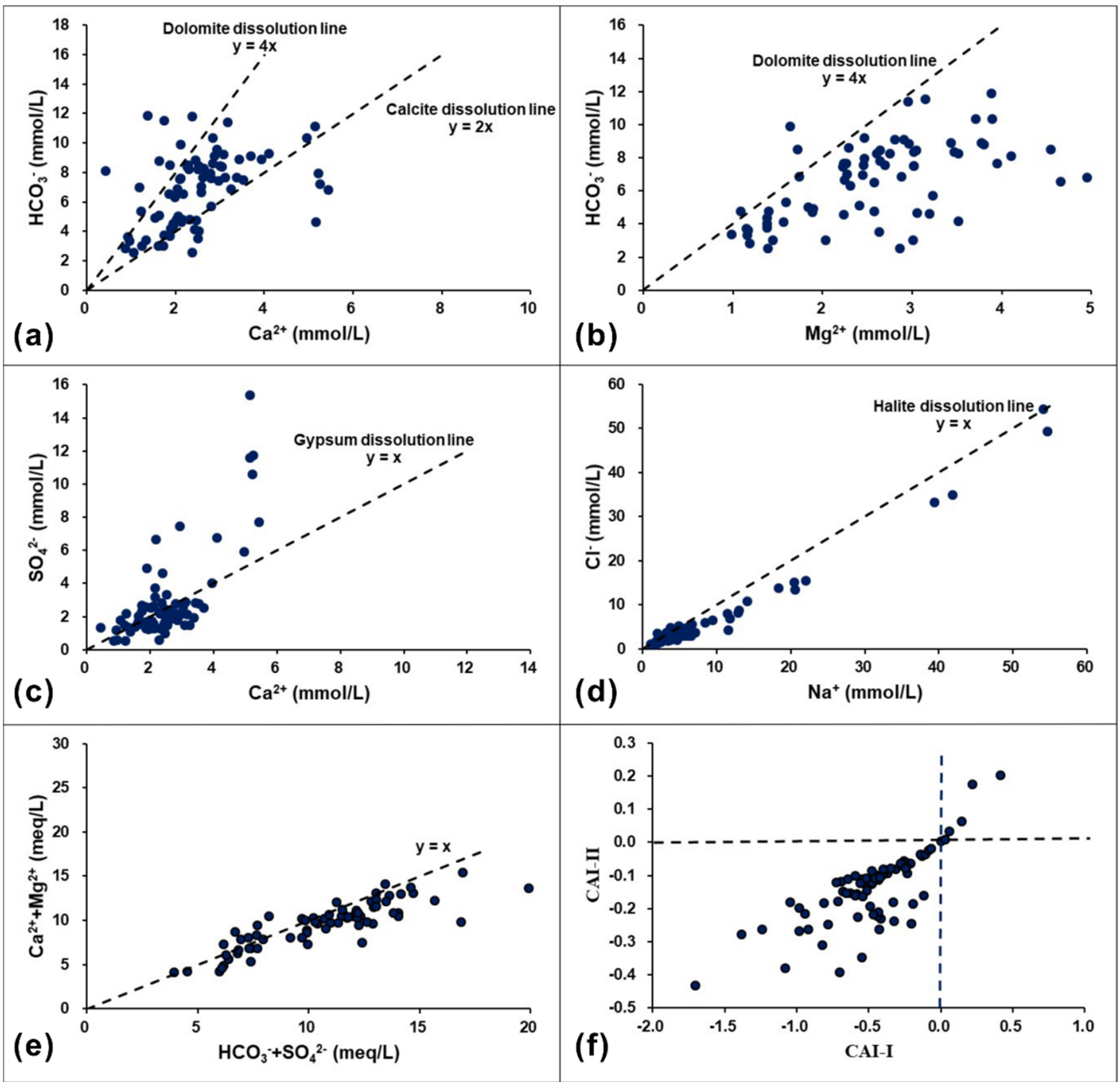

Figure 7. Scatter plots of some pairs of ions and Schoeller indices for phreatic water: (a) $\mathrm{Ca}^{2+}$ vs. $\mathrm{HCO}_{3}{ }^{-}$, (b) $\mathrm{Mg}^{2+}$ vs. $\mathrm{HCO}_{3}{ }^{-}$, (c) $\mathrm{Ca}^{2+}$ vs. $\mathrm{SO}_{4}{ }^{2-}$, (d) $\mathrm{Na}^{+}$vs. $\mathrm{Cl}^{-}$, (e) $\left(\mathrm{Ca}^{2+}+\mathrm{Mg}^{2+}\right)$ vs. $\left(\mathrm{HCO}_{3}{ }^{-}+\right.$ $\left.\mathrm{SO}_{4}{ }^{2-}\right)$, (f) CAI-I vs. CAI-II.

The plots between the ion pairs derived from the dissolution of evaporite minerals (gypsum and halite) are shown in Figure 7c,d. The ideal ratios of the two pairs would be 1 if they are only controlled by their chemical reactions (Equations (9) and (10)). In real cases, most samples are plotted around 1:1 line (Figure 7c), explaining the key role of gypsum dissolution controlling the two ions. However, a few samples appear to have significant higher $\mathrm{SO}_{4}{ }^{2-}$ contents than $\mathrm{Ca}^{2+}$, which implies extra $\mathrm{SO}_{4}{ }^{2-}$ inputs such as sulfate-containing minerals and chemical fertilizers. Groundwater samples follow the 1:1 line of halite dissolution, indicating that both $\mathrm{Na}^{+}$and $\mathrm{Cl}^{-}$were basically released by halite into the groundwater (Figure 7d). However, the displacement of most points to an excess of $\mathrm{Na}^{+}$content, points to cation exchange causing an increment of $\mathrm{Na}^{+}$(Equation (11)).

$$
\begin{gathered}
\mathrm{CaSO}_{4} \bullet 2 \mathrm{H}_{2} \mathrm{O} \Leftrightarrow \mathrm{Ca}^{2+}+\mathrm{SO}_{4}^{2-}+2 \mathrm{H}_{2} \mathrm{O} \\
\mathrm{NaCl} \rightarrow \mathrm{Na}^{+}+\mathrm{Cl}^{-} \\
2 \mathrm{NaX}+\mathrm{Ca}^{2+} \rightarrow \mathrm{CaX} 2+2 \mathrm{Na}^{+} \\
\mathrm{CaX} 2+2 \mathrm{Na}^{+} \rightarrow 2 \mathrm{NaX}+\mathrm{Ca}^{2+}
\end{gathered}
$$


The scatter plot of $\left(\mathrm{Ca}^{2+}+\mathrm{Mg}^{2+}\right)$ versus $\left(\mathrm{HCO}_{3}{ }^{-}+\mathrm{SO}_{4}{ }^{2-}\right)$ shows that most samples are scattered along the 1:1 line, and most samples are plotted under the line, indicating an excess of $\left(\mathrm{HCO}_{3}{ }^{-}+\right.$ $\left.\mathrm{SO}_{4}{ }^{2-}\right)$ over $\left(\mathrm{Ca}^{2+}+\mathrm{Mg}^{2+}\right)$ in some groundwater samples (Figure 7e). Therefore, the combined effects of dissolution of carbonates and gypsum along with the cation exchange (Equation (11)) are mainly responsible for the formation of these chemical elements. Additionally, the Schoeller indices (CAI-I and CAI-II) developed by Schoeller [36] are important indicators of the ion exchange occurring in aquifer systems. These indices were calculated by the following Equations (13) and (14), where ions are expressed in meq/L. The cation exchange process (Equation (11)) denoted by negative CAI values,

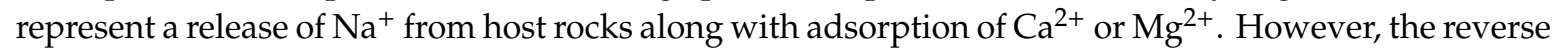
ion exchange characterized by positive CAI values, signifies an exchange of $\mathrm{Na}^{+}$in groundwater with $\mathrm{Ca}^{2+}$ or $\mathrm{Mg}^{2+}$ of aquifer matrix. (Equation (12)). It is clear that the vast majority of samples have negative CAI values (Figure 7f), indicating that cation exchange is one of important geochemical processes. During that exchange process, $\mathrm{Na}^{+}$is released from host rocks in groundwater along with $\mathrm{Ca}^{2+}$ absorption, as described in Equation (11). Only a few samples have positive CAI values, suggesting that $\mathrm{Ca}^{2+}$ or $\mathrm{Mg}^{2+}$ is dissolved into groundwater along with $\mathrm{Na}+$ absorption. Obviously, the reverse ion exchange plays a minor role in the variation of major cations.

$$
\begin{gathered}
\mathrm{CAI}-\mathrm{I}=\frac{\mathrm{Cl}^{-}-\left(\mathrm{Na}^{+}+\mathrm{K}^{+}\right)}{\mathrm{Cl}^{-}} \\
\mathrm{CAI}-\mathrm{II}=\frac{\mathrm{Cl}^{-}-\left(\mathrm{Na}^{+}+\mathrm{K}^{+}\right)}{\mathrm{HCO}_{3}{ }^{-}+\mathrm{SO}_{4}{ }^{2-}+\mathrm{CO}_{3}{ }^{2-}+\mathrm{NO}_{3}-}
\end{gathered}
$$

The saturation indices (SI) can provide further evidence of minerals' dissolution and precipitation patterns, which were computed using the PHREEQC software [37]. Figure 8 presents the scatterplots of SI against TDS for all phreatic water samples. The results showed that phreatic water was undersaturated about gypsum and halite, which were certainly dissolving in the aquifer (Figure $8 a, b$ ). The SI values of gypsum and halite oscillated in the ranges of -2.30 to -0.61 and -7.59 to -4.32 , with averages of -1.38 and -6.42 , respectively. Note that these evaporite minerals' SI values are positively proportional to TDS, indicating that these evaporites are important contributors for TDS increment by releasing the chemical elements $\left(\mathrm{Ca}^{2+}, \mathrm{SO}_{4}{ }^{2-}, \mathrm{Na}^{+}\right.$and $\left.\mathrm{Cl}^{-}\right)$. However, the groundwater was oversaturated with the carbonate minerals (i.e., calcite and dolomite). The SI values of calcite and dolomite varied from 0.19 to 0.96 and from 0.37 to 2.19 , with mean values of 0.60 and 1.38 , respectively. More importantly, as shown in Figure 8c,d, TDS is poorly correlated with SI values of calcite and dolomite, suggesting that such ions $\left(\mathrm{Ca}^{2+}, \mathrm{Mg}^{2+}\right.$ and $\left.\mathrm{HCO}_{3}{ }^{-}\right)$are introduced into groundwater by the fast dissolution process of these carbonate minerals at the initial stages of water-rock interaction [38].

The Gibbs plots are widely used to explain the roles of rock weathering, precipitation, and evaporation in the formation of water chemistry [39]. The distributed characteristics of samples support the conclusion that the evolution of groundwater chemistry in the domain is collectively controlled by rock weathering and evaporation (Figure 9). The interaction between groundwater and the surrounding aquifer medium plays a key role in shaping the status of groundwater chemistry. As mentioned before, chemical compositions in groundwater are strongly regulated by various geochemical processes.

It is clear that the rock weathering is the dominant mechanism controlling the phreatic water chemistry with TDS $<1 \mathrm{~g} / \mathrm{L}$. However, samples with TDS $>1 \mathrm{~g} / \mathrm{L}$ are gradually shifted to the upper right of the diagram and fall in evaporation dominance category (Figure 9a), connoting that the phreatic water chemistry is not only controlled by rock weathering, but also by evaporation. For most groundwater samples, the $\mathrm{Na}^{+} /\left(\mathrm{Na}^{+}+\mathrm{Ca}^{2+}\right)$ ratio spreads from low to high with an increment of TDS, indicating that cation exchange possibly plays a role by $\mathrm{Na}+$ desorption and the absorption of $\mathrm{Ca}^{2+}$ or $\mathrm{Mg}^{2+}$. In addition, it is clear that the $\mathrm{Cl}^{-} /\left(\mathrm{Cl}^{-}+\mathrm{HCO}_{3}^{-}\right)$ratio in phreatic water increases along with 
the increment of TDS (Figure 9b), supporting that evaporation-crystallization in the irrigated region is likely to promote the elevated $\mathrm{Cl}^{-}$content.
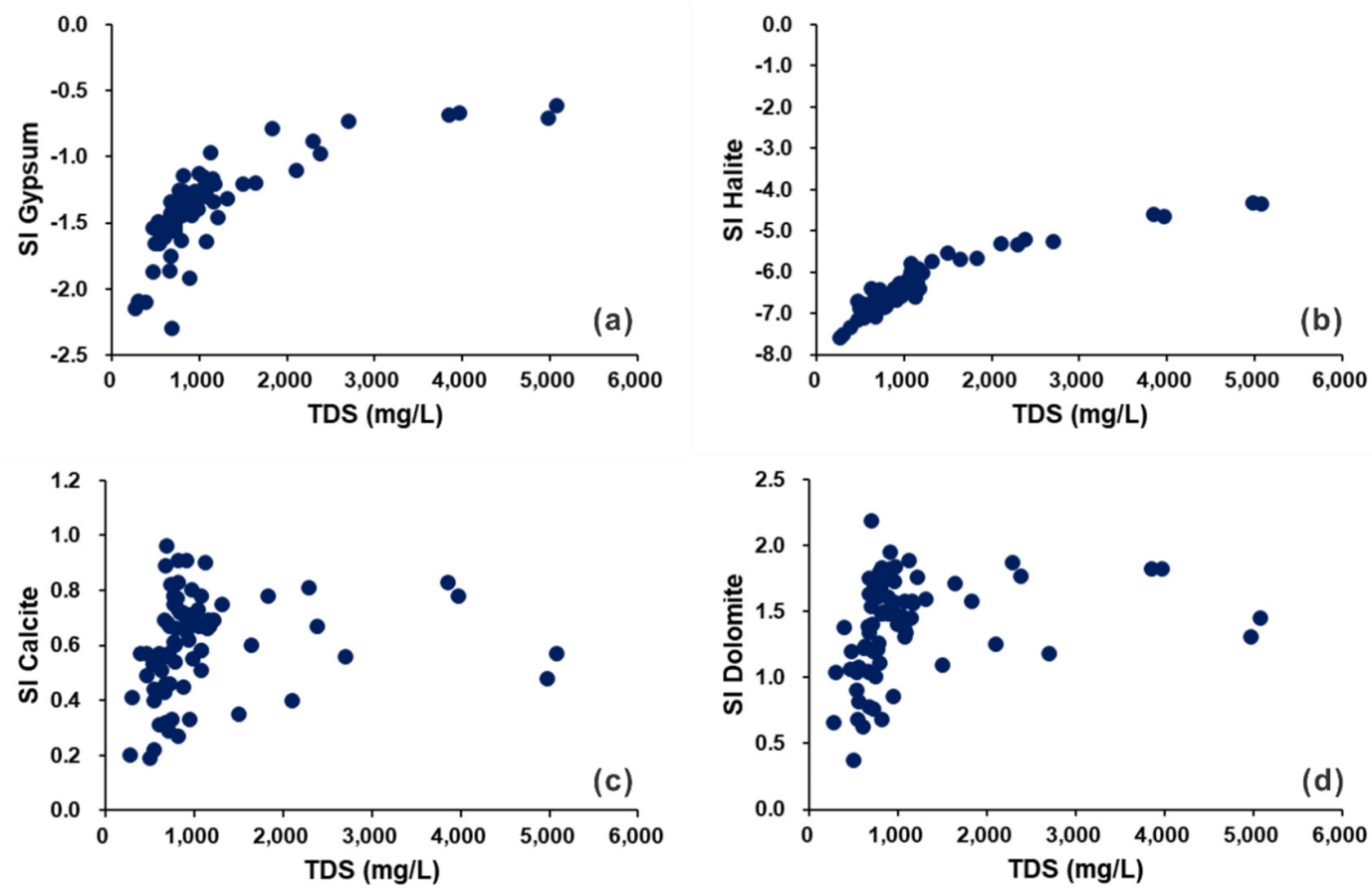

Figure 8. Scatter plots of the major minerals' saturation indices against TDS: (a) gypsum, (b) halite, (c) calcite and (d) dolomite.
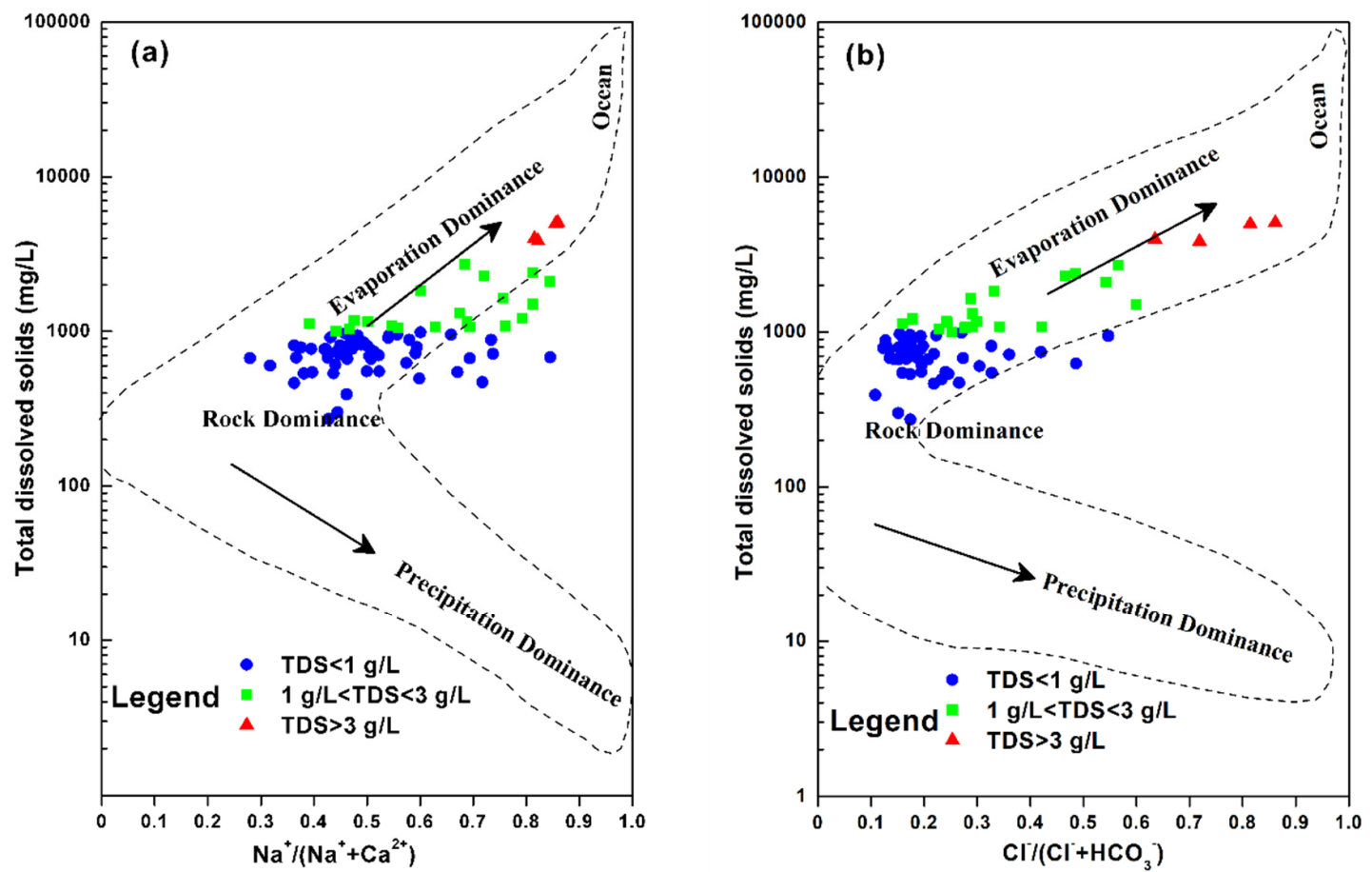

Figure 9. Gibbs plots of groundwater samples in the study area: (a) $\mathrm{Na}^{+} /\left(\mathrm{Na}^{+}+\mathrm{Ca}^{2+}\right)$ and $(\mathbf{b}) \mathrm{Cl}^{-} /\left(\mathrm{Cl}^{-}\right.$ $\left.+\mathrm{HCO}_{3}{ }^{-}\right)$, versus TDS. 


\section{Conclusions}

Groundwater quality assessment is one of the most important environmental issues relating to sustainable development, especially in the Yinchuan Plain, which is characterized by an extremely arid climate and is threatened by the significant reduction in water transfer from the Yellow River. In this study, the groundwater quality was evaluated and the associated hydrogeochemical processes were identified. Results showed that the majority of water quality parameters were within the permissible limits of WHO with a few exceptions. The patterns of the dominance of the major cations and anions were $\mathrm{Na}^{+}>\mathrm{Ca}^{2+}>\mathrm{Mg}^{2+}>\mathrm{K}^{+}$and $\mathrm{HCO}_{3}{ }^{-}>\mathrm{SO}_{4}{ }^{2-}>\mathrm{Cl}^{-}>\mathrm{NO}_{3}{ }^{-}$. The severity of the localized nitrate contamination becomes apparent in the pluvial-alluvial plain, mainly caused by the high loads of nitrogen fertilizers. Water quality index (WQI) showed that the phreatic water was excellent or good in most areas west of the Yellow River. However, the groundwater was found to be poor or very poor quality, and even unsuitable for drinking in some places east of the Yellow River. Additionally, the water quality for irrigation purposes was assessed via multiple indicators such as SAR, RSC, $\mathrm{Na} \%, \mathrm{PI}$, and MH. In terms of SAR, RSC, Na\%, and PI, most phreatic water samples had no sodium hazard and were suitable for irrigation. However, almost $62 \%$ of the water samples had the magnesium hazard (MH) for agricultural purposes, which may damage soil structure and inhibit the yield of crops. Hence, proper measures are needed to address this issue.

Furthermore, the hydrochemistry analysis illustrated that the phreatic water evolved from low mineralized $\mathrm{Ca}-\mathrm{Mg}-\mathrm{HCO}_{3}$ and $\mathrm{Ca}-\mathrm{Mg}-\mathrm{HCO}_{3}-\mathrm{SO}_{4}$ water (TDS $<1 \mathrm{~g} / \mathrm{L}$ ), through brackish $\mathrm{Na}-\mathrm{Ca}-\mathrm{HCO}_{3}-\mathrm{SO}_{4}$ and Na-Mg-SO $4-\mathrm{Cl}$ water $(1<\mathrm{TDS}<3 \mathrm{~g} / \mathrm{L})$, to highly saline $\mathrm{Na}-\mathrm{Cl}-\mathrm{SO}_{4}$ water (TDS $>3 \mathrm{~g} / \mathrm{L}$ ). The major geochemical processes responsible for the observed chemical compositions in the phreatic water are the dissolution/precipitation of gypsum, halite, dolomite, and calcite, along with the cation exchange. Rock weathering and evaporation jointly predominate the evolution of phreatic water chemistry in the study area. In a broad sense, the findings of this work have important implications for the sustainable management of groundwater resources in such irrigated regions along the upper Yellow River.

Author Contributions: Data curation, L.G. and H.L.; Formal analysis, F.L.; Investigation, L.Y., Y.M. and B.L.; Project administration, L.Y.; Resources, Z.Z.; Writing—original draft, F.L.; Writing-review \& editing, L.Y. All authors have read and agreed to the published version of the manuscript.

Funding: This research was financially supported by the research fund of Ningxia Geological Exploration (Grant No. HZ20170040-I); the project of urban geological survey in the Yinchuan metropolitan area; the project of Ningxia Youth Talents of Science and Technology. Fei Liu acknowledges the support from the China Scholarship Council (Grant No. 201808130026) and the Department of Education of Hebei Province (Grant No. QN2018076).

Acknowledgments: The authors are grateful to our colleagues for their assistance in data collection and field investigation. Special thanks go to the editor and the reviewers for their critical reviews and valuable suggestions.

Conflicts of Interest: The authors declare no conflict of interest.

\section{References}

1. Adimalla, N.; Venkatayogi, S. Geochemical characterization and evaluation of groundwater suitability for domestic and agricultural utility in semi-arid region of Basara, Telangana State, South India. Appl. Water Sci. 2018, 8, 44. [CrossRef]

2. Li, P.; Qian, H.; Howard, K.W.F.; Wu, J. Building a new and sustainable "Silk Road economic belt". Environ. Earth Sci. 2015, 74, 7267-7270. [CrossRef]

3. Qian, H.; Li, P.; Howard, K.W.; Yang, C.; Zhang, X. Assessment of groundwater vulnerability in the Yinchuan Plain, Northwest China using OREADIC. Environ. Monit. Assess. 2012, 184, 3613-3628. [CrossRef] [PubMed]

4. Zhang, X.; Qian, H.; Chen, J.; Qiao, L. Assessment of Groundwater Chemistry and Status in a Heavily Used Semi-Arid Region with Multivariate Statistical Analysis. Water 2014, 6, 2212-2232. [CrossRef]

5. Jing, X.; Yang, H.; Wang, W.; Cao, Y. Hydro-geochemical simulation for the evolution of groundwater quality in Yinchuan Plain, China. Hydrol. Sci. J. 2016, 61, 2284-2294. [CrossRef] 
6. Chen, J.; Wu, H.; Qian, H.; Gao, Y. Assessing Nitrate and Fluoride Contaminants in Drinking Water and Their Health Risk of Rural Residents Living in a Semiarid Region of Northwest China. Expo. Health 2016, 9 , 183-195. [CrossRef]

7. Richards, L.A. Diagnosis and Improvement of Saline and Alkali Soils. Soil Sci. 1954, 78, 154. [CrossRef]

8. Jain, C.K.; Vaid, U. Assessment of groundwater quality for drinking and irrigation purposes using hydrochemical studies in Nalbari district of Assam, India. Environ. Earth Sci. 2018, 77. [CrossRef]

9. Han, D.; Post, V.E.A.; Song, X. Groundwater salinization processes and reversibility of seawater intrusion in coastal carbonate aquifers. J. Hydrol. 2015, 531, 1067-1080. [CrossRef]

10. Argamasilla, M.; Barbera, J.A.; Andreo, B. Factors controlling groundwater salinization and hydrogeochemical processes in coastal aquifers from southern Spain. Sci. Total Environ. 2016, 580, 50-68. [CrossRef]

11. Wang, L.; Dong, Y.; Xie, Y.; Song, F.; Wei, Y.; Zhang, J. Distinct groundwater recharge sources and geochemical evolution of two adjacent sub-basins in the lower Shule River Basin, northwest China. Hydrogeol. J. 2016, 24, 1967-1979. [CrossRef]

12. Tahoora, S.N.; Sefie, A.; Aris, A.Z. The long-term impacts of anthropogenic and natural processes on groundwater deterioration in a multilayered aquifer. Sci. Total Environ. 2018, 630, 931-942. [CrossRef]

13. Wei, W.; Hui, Q. Research on the Countermeasures of the Reduction in Water Transfer from the Yellow River in Yinchuan Plain, China. Procedia Environ. Sci. 2011, 8, 97-102. [CrossRef]

14. Qian, H.; Li, P. Hydrochemical characteristics of groundwater in Yinchuan plain and their control factors. Asian J. Chem. 2011, 23, 2927.

15. Li, P.; Wu, J.; Qian, H.; Zhang, Y.; Yang, N.; Jing, L.; Yu, P. Hydrogeochemical Characterization of Groundwater in and Around a Wastewater Irrigated Forest in the Southeastern Edge of the Tengger Desert, Northwest China. Expo. Health 2016, 8, 331-348. [CrossRef]

16. Qian, H.; Wu, J.; Zhou, Y.; Li, P. Stable oxygen and hydrogen isotopes as indicators of lake water recharge and evaporation in the lakes of the Yinchuan Plain. Hydrol. Process 2014, 28, 3554-3562. [CrossRef]

17. Khalid, S. An assessment of groundwater quality for irrigation and drinking purposes around brick kilns in three districts of Balochistan province, Pakistan, through water quality index and multivariate statistical approaches. J. Geochem. Explor. 2019, 197, 14-26. [CrossRef]

18. Xiao, J.; Wang, L.; Deng, L.; Jin, Z. Characteristics, sources, water quality and health risk assessment of trace elements in river water and well water in the Chinese Loess Plateau. Sci. Total Environ. 2019, 650, 2004-2012. [CrossRef]

19. World Health Organization (Ed.) Guidelines for Drinking-Water Quality, 4th ed.; World Health Organization: Geneva, Switzerland, 2011.

20. Li, P.; Tian, R.; Liu, R. Solute Geochemistry and Multivariate Analysis of Water Quality in the Guohua Phosphorite Mine, Guizhou Province, China. Expo. Health 2018, 11, 81-94. [CrossRef]

21. Sawyer, C.N.; McCarty, P.L. Chemistry for sanitary engineers. In Chemistry for Sanitary Engineers; McGraw-Hill: New York, NY, USA, 1967.

22. Adimalla, N.; Qian, H. Groundwater quality evaluation using water quality index (WQI) for drinking purposes and human health risk (HHR) assessment in an agricultural region of Nanganur, south India. Ecotoxicol. Environ. Saf. 2019, 176, 153-161. [CrossRef]

23. He, B.; He, J.; Wang, L.; Zhang, X.; Bi, E. Effect of hydrogeological conditions and surface loads on shallow groundwater nitrate pollution in the Shaying River Basin: Based on least squares surface fitting model. Water Res. 2019, 163, 114880. [CrossRef] [PubMed]

24. Chowdhury, S.; Mazumder, M.A.J.; Al-Attas, O.; Husain, T. Heavy metals in drinking water: Occurrences, implications, and future needs in developing countries. Sci. Total Environ. 2016, 569-570, 476-488. [CrossRef] [PubMed]

25. Jiang, Y.; Guo, H.; Jia, Y.; Cao, Y.; Hub, C. Principal component analysis and hierarchical cluster analyses of arsenic groundwater geochemistry in the Hetao basin, Inner Mongolia. Geochemistry 2015, 75, 197-205. [CrossRef]

26. He, J.; Charlet, L. A review of arsenic presence in China drinking water. J. Hydrol. 2013, 492, 79-88. [CrossRef]

27. Keesari, T.; Ramakumar, K.L.; Chidambaram, S.; Pethperumal, S.; Thilagavathi, R. Understanding the hydrochemical behavior of groundwater and its suitability for drinking and agricultural purposes in Pondicherry area, South India-A step towards sustainable development. Groundw. Sustain. Dev. 2016, 2-3, 143-153. [CrossRef] 
28. Eaton, F.M. Significance of carbonates in irrigation waters. Soil Sci. 1950, 69, 123-134. [CrossRef]

29. Selvakumar, S.; Ramkumar, K.; Chandrasekar, N.; Magesh, N.S.; Kaliraj, S. Groundwater quality and its suitability for drinking and irrigational use in the Southern Tiruchirappalli district, Tamil Nadu, India. Appl. Water Sci. 2014, 7, 411-420. [CrossRef]

30. Abd El-Aziz, S.H. Evaluation of groundwater quality for drinking and irrigation purposes in the north-western area of Libya (Aligeelat). Environ. Earth Sci. 2017, 76, 147. [CrossRef]

31. Singh, P.K.; Panigrahy, B.P.; Verma, P.; Kumar, B. Evaluation of the Surface Water Quality Index of Jharia Coal Mining Region and Its Management of Surface Water Resources. In Environmental Pollution; Springer: Singapore, 2018; pp. 429-437.

32. Doneen, L.D. Water Quality for Irrigated Agriculture. In Plants in Saline Environments; Poljakoff-Mayber, A., Gale, J., Eds.; Springer: Berlin/Heidelberg, Germany, 1975; pp. 56-76. [CrossRef]

33. Wu, H.; Chen, J.; Qian, H.; Zhang, X. Chemical Characteristics and Quality Assessment of Groundwater of Exploited Aquifers in Beijiao Water Source of Yinchuan, China: A Case Study for Drinking, Irrigation, and Industrial Purposes. J. Chem. 2015, 2015, 1-14. [CrossRef]

34. Piper, A.M. A Graphic Procedure in the Geochemical Interpretation of Water Analysis; US Department of the Interior, Geological Survey, Water Resources Division, Ground Water Branch: Washington, DC, USA, 1953.

35. Back, W.; Hanshaw, B.B.; Pyle, T.E.; Plummer, L.N.; Weidie, A.E. Geochemical significance of groundwater discharge to the formation of Caleta Zel Ha, Quintana Roo, Mexico. Water Resour. Res. 1979, 15, 1521-1535. [CrossRef]

36. Schoeller, H. Qualitative Evaluation of Groundwater Resources; UNESCO: Paris, France, 1965; pp. 54-83.

37. Parkhurst, D.L.; Appelo, C. PHREEQC2 User's Manual and Program, Water-Resources Investigations Report; US Geological Survey: Denver, CO, USA, 2004.

38. Liu, F.; Wang, S.; Wang, L.; Shi, L.; Song, X.; Yeh, T.-C.J.; Zhen, P. Coupling hydrochemistry and stable isotopes to identify the major factors affecting groundwater geochemical evolution in the Heilongdong Spring Basin, North China. J. Geochem. Explor. 2019, 205, 106352. [CrossRef]

39. Gibbs, R.J. Mechanisms controlling world water chemistry. Science 1970, 170, 1088-1090. [CrossRef] [PubMed] 